\title{
糖尿病透析患者の身体的精神的特質と食事療法
}

\author{
金澤 良枝中尾 俊 之* \\ 東京都済生会中央病院 同腎臓内科* \\ (平成 1 年 12 月 11 日受付, 同 2 年 1 月 17 日受理)
}

key words：糖尿病性腎不全，透析患者，身体的特質，性格，食事療法

〈要旨〉

食事療法を通して DM 透析患者の身体的精神的特質について, 非 DM 透析患者と比較し検討を加えた。

DM 透析患者 74 名 (HD43, CAPD 31)，非 DM 透析患者 60 名 (HD45, CAPD15) に対し, 食事捸取量調査, 食事 療法に対する態度の評価, 透析間体重増加量調査を行った。また，身体的特徵を Karnofsky scale，精神的特徵を Kretschmer の性格類型論を詫摩が改変した分類により検討した.

その結果，エネルギ一遵守率（指示エネルギー量士100 kcal 以内に守られている者）は，HD ではDM 群 46.5\%, 非 DM 群 44.4\%で有意差を認めなかった。 CAPD では DM 群 $48.4 \%$ で非 DM 群 $33.3 \%$ に比較しエネルギー遵守率 が有意 $(p<0.05)$ に良好であった。タンパク質遵守率(指示タンパク質量士5 g 以内に守られている者) は, HD, CAPD とも両者間に有意差は認めなかった。 また, DM 群では食事療法を家族に依存している者が $45.9 \%$ あった。尿量 300 $\mathrm{m} l /$ 日以下の $\mathrm{HD}$ 者の 1 日当りの体重増加量は, DM 群 0.98 $0.41 \mathrm{~kg} /$ 日, 非 DM 群 $1.09 \pm 0.33 \mathrm{~kg} /$ 日で, 両者間

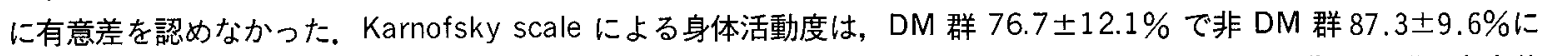
比較し有意 $(p<0.005)$ に低值であった。性格類型 $(Z, S, E, H, N, P$ 型) の出現頻度は, DM 群, 非 DM 群に有意差 を認めなかった。食事療法の遵守と性格は DM 群, 非 DM 群とも食事療法不良群にS型性格（分裂質）の出現頻度 が有意 $(p<0.05)$ に高かった.

以上より，DM 透析患者の食事療法の遵守は非 DM 者と同等に行われており，食事療法の面からみた DM 透析患 者の身体的精神的特質は, 身体活動度は低いものの性格類型分布は非 DM 者と差を認めず, DM 者に特にわがままが 多いなどの性格の偏向は認められなかった。

\section{Psychological and physical characteristics and diet therapy in diabetic dialysis patients}

Yoshie Kanazawa, Toshiyuki Nakao, M. D.

Division of Nutrition and Nephrology, Saiseikai Central Hospital

Investigating the course and outcome of dietary education we estimated psychological and physical characteristics of diabetic dialysis patients in comparison with non-diabetic dialysis patients. Food diaries, attitudes to diet therapy, body weight increments in the inter-dialytic period, Karnofsky's scale and the frequency of Kretschmer's character types (modified by Takuma) were studied in 74 diabetic dialysis patients (HD 43, CAPD 31) and 60 non-diabetic dialysis patients (HD 45, CAPD 15).

In hemodialysis patients, $46.5 \%$ of diabetics and $44.4 \%$ of non-diabetics adhered to their prescribed energy intake (within $\pm 100 \mathrm{kcal}$ per day), and there was no significant difference between diabetic and non-diabetic groups. On the other hand, in CAPD patients the rate of adherence to the prescribed energy intake was significantly higher in diabetics $(48.4 \%)$ than in non-diabetics $(33.3 \%) \quad(p<0.05)$. No significant differences were observed between diabetics and non-diabetics on dialysis in the rate of adherence to the prescribed protein intake (within \pm $5.0 \mathrm{~g}$ a day). Of diabetic dialysis patients, $45.9 \%$ depended on their families for dietary control. In the hemodialysis patients with residual urine volumes less than $300 \mathrm{ml}$ per day, body weight increments in the inter-dialytic period

金澤 良枝 東京都済生会中央病院

干 108 港区三田 1-4-17 (03-451-8211) were $0.99 \pm 0.41 \mathrm{~kg} /$ day in diabetics and $1.09 \pm 0.33$

$\mathrm{kg} /$ day in non-diabetics, and there were no significant 
differences between the two groups. Karnofsky's scale scores were significantly low in diabetics $(76.7 \pm 12.1 \%)$ as compared to non-diabetics $(87.3 \pm 9.6 \%)(p<0.005)$. There were no significant differences in the frequency of each character type (Z, S, E, H, N, P) between diabetics and non-diabetics on dialysis treatment. In both diabetics and non-diabetics whose character type was $S$ (schizophrenic), the rate of adherence to the prescribed diet was significantly low in comparison to the patients of other character type $(p<0.05)$.

In conclusion, the rate of adherence to the prescribed diet in diabetic dialysis patients was equal to that in non -diabetic dialysis patients. Although physical activity in diabetic dialysis patients was lower than that in non -diabetic dialysis patients, the frequency of character types were not significantly different between the two groups. No psychological characteristic peculiarity such as greater disobedience or selfishness could be observed in diabetic dialysis patients in comparison with non-diabetic dialysis patients.

\section{緒言}

梼尿病性腎症は，糖尿病 (DM) 患者のうち，血糖コン トロール不良者や DM籊患歴の長い者に発症頻度が高い といわれている11. DM コントロールの基本は食事療法 であり，長期にわたり食事療法を厳格に守ることが DM コントロールを良好とし，ひいては細小血管症の発症防 止に良い影響をもたらすとされている

したがって，DM 性腎症を発症して透析療法が必要と なるような患者では，元来わがままな性格が多く，食事 管理不良者が多いのではないかと思われがちである。し， かし我々の経験ではこれは必ずしも妥当とは考え難い。 そこで食事療法を通して DM 透析患者の身体的精神的 特質について非 DM 透析患者と比較し検討を加えた。

\section{方法}

対象は, DM 透析患者 74 名(HD 43 名, CAPD 31 名) である. 対象者の平均年齢は $58.6 \pm 10.4$ 歳, 平均透析歴 は HD 34.9土27.1 か月, CAPD 23.0土11.1 か月である。 また, 非 DM 透析患者 60 名 (HD 45 名, CAPD 15 名) を対照群とした。非 DM 透析患者の平均年齢は 55.5 土 15.5歳, 平均透析歴は HD 46.0土42.1 か月, CAPD 27.5 \pm 16.5 か月である.

対象者に対し，食事摄取量調查㧍よび食事療法に対す る態度の評価, 透析間体重増加量調査を行った。食事摄 取量調査は連続 4 日間の献立表から算出し, 献立記入不 明点は聞きとりにより修正を加えて摂取量の正確性を期 した. 食事療法の遵守率は， $3 \sim 6$ か月間の平均摄取量 が指示エネルギー量士 $100 \mathrm{kcal}$ 以内, 平均摂取タンパク 質量が指示タンパク質量 $\pm 5 \mathrm{~g}$ 以内を良好群とした。さ らに患者扔よび調理者に面接を行い食事療法に対する考 え方を聴取し, 調査献立表と合わせて評価を加えた。評 価基準は， A. いつも指示量を守っている． B. 指示量 の 7 割程度守っている。C．あまり守る気がしない．D. 無関心. E.家族にまかせているの 5 ランクに分類し行っ た。透析間体重増加量は，1 加間の観察より 1 日平均 体重増加量を算出した。
表 1 Karnofsky scale 評価基準

\begin{tabular}{|c|c|c|}
\hline$\%$ & & 基 準 \\
\hline 100 & -1 & 正 常 \\
\hline 90 & 1 & 努力により通常の活動が可能 \\
\hline 80 & - & 家庭外活動の大部分が可能 \\
\hline 70 & -1 & 日常生活動作の一部に介助必要 \\
\hline 60 & $1-$ & 衣類の着脱や歩行に介助必要 \\
\hline 50 & 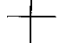 & ほぼ全面介助 \\
\hline 40 & -1 & 合併症の併発 \\
\hline 30 & 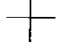 & Poor. 悪い病状 \\
\hline 20 & -1 & 重篤な病状 \\
\hline 10 & \begin{tabular}{l|l}
- \\
\end{tabular} & 生命の危険あり \\
\hline 0 & + & 死 亡 \\
\hline
\end{tabular}

また，対象者の身体的特徵を Karnofsky scale ${ }^{5)}$ によ り検討し, 精神的特徵を Kretschmer の性格類型論6) 詫摩が改変した分類”により検討した. Karnofsky scale の評価基準は表 1 の通りで判定はスタッフ 5 名が個々に 対象者の評価を行い，それぞれ最高值と最低值を削除し た平均值とした，Kretschmer の性格類型は，同様のス タッフによる協議により決定した。

\section{結果}

1. 食事療法の遵守率

HD ではエネルギー遵守良好群が DM 群 46.5\%, 非 DM 群 44.4\%, タンパク質遵守良好群が DM 群 $37.2 \%$, 非 DM 群 35.6\%でエネルギー遵守率, タンパク質遵守 率とも両者に有意差は認めなかった。

CAPD では，エネルギー遵守良好群が DM 群 $48.4 \%$, 非 DM 群 $33.3 \%$ で有意差 $(\mathrm{p}<0.05)$ を認めた。タンパ ク質遵守良好群は，DM 群 $25.8 \%$ ，非 DM 群 $26.7 \%$ で 有意差は認めなかった（図 1)。

2. 食事療法に対する態度の評価

患者本人では, DM 群はA（いつも指示量を守ってい る） $4.1 \% ， \mathrm{~B}$ (指示量の 7 割程度守っている) $18.9 \%$, C (あまり守る気がしない) $23.0 \%, D$ (無関心) $8.1 \%$ ， $\mathrm{E}$ (家族にまかせている) $45.9 \%$ でった。同様に非 DM 


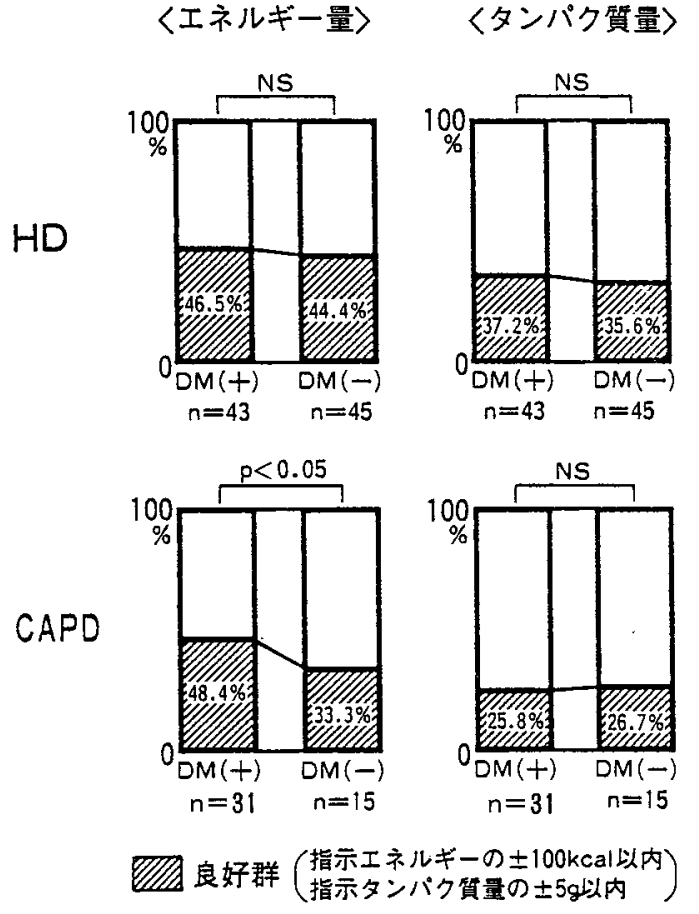

図 1 食事摂取エネルギー量, タンパク質量の遵 守率一DM 群と非 DM 群の比較一

図上：血液透析例, 図下：CAPD 例

群では，A $11.7 \% ， \mathrm{~B} 43.3 \%$, C $15.0 \%$, D $10.0 \%$, E 20.0\%であった. DM 群では食事療法を家族に依存し ている者が約半数を占めた。ささらに調理者に対して同様 に評価すると DM 群では, A $27.0 \%$, B $44.6 \%, C$ 18.9\%，D 9.5\%，非 DM 群ではA $11.7 \% ， \mathrm{~B} 65.0 \%$, C 13.3\%, D 10.0\%であった. C, D とした者は, DM 群 と非 DM 群に差は認められなかった（図 2 ).

\section{1 日の体重増加量}

尿量 $300 \mathrm{ml} /$ 日以下の血液透析患者の，1 日当りの体 重増加量は, DM 群 $0.98 \pm 0.41 \mathrm{~kg} /$ 日, 非 DM 群 $1.09 \pm$ $0.33 \mathrm{~kg} /$ 日で両者に有意差は認められなかった (図 3 ).

4. Karnofsky scale による身体活動度

Karnofsky scale による身体活動度は DM 群 $76.7 \pm$ $12.1 \%$, 非 DM 群 $87.3 \pm 9.6 \%$ で DM 群が有意 $(\mathrm{p}<$ 0.005）に低值であり，身体活動度が低かった（表 2 ）。

5. 性格類型論による分類

性格類型の出現頻度は，DM 群では $Z$ 型（躁うつ質） 16 名 (21.6\%), $\mathrm{S}$ 型 (分裂質) 17 名 (23.0\%), $\mathrm{E}$ 型 (粘 着質) 11 名 (14.9\%), $\mathrm{H}$ 型 (䫒示性性格) 12 名 (16.2\%), $\mathrm{N}$ 型 (神経質) 6 名 (8.1\%), P 型(偏執病質) 12 名 (16.2\%) であり, 非 DM 群では, Z 型 18 名 (30.0\%), S 型 13 名 $(21.6 \%), \mathrm{E}$ 型 10 名 (16.7\%), $\mathrm{H}$ 型 7 名 $(11.7 \%)$,

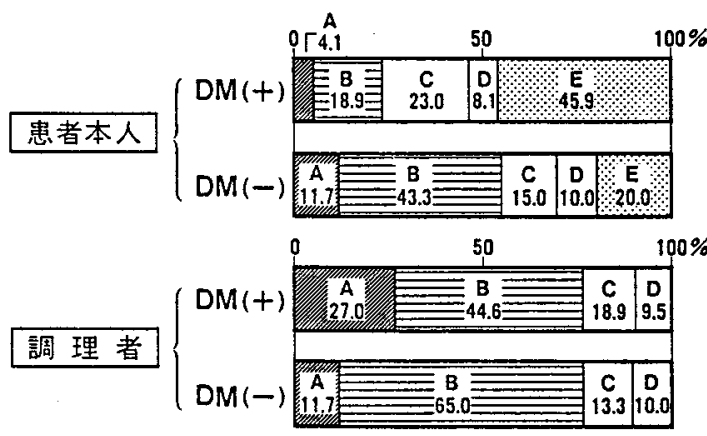

A いつも指示量を守っている

B 指示量の7割程度守っている

Cあまり守る気はしない

D無関心

E家族にまかせている

図 2 食事療法に対する態度の評価 -DM 群と非 DM 群の比較図上：患者本人の態度, 図下：調 理者の態度

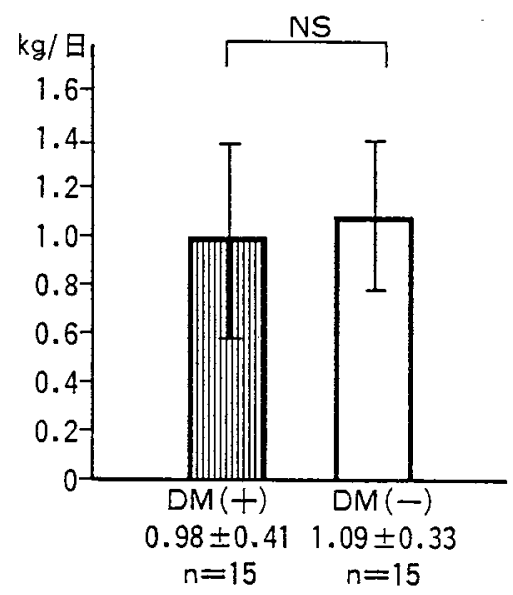

図 31 日の体重増加量(尿量 $300 \mathrm{~m} l$ /日以下の血 液透析患者）-DM 群と非 DM 群の比較一

表 2 Karnofsky scale による身体活動度 -DM 群と非 DM 群の比較一

\begin{tabular}{ll}
\hline $\mathrm{DM}(+) \mathrm{n}=74$ & $76.7 \pm 12.1$ \\
$\mathrm{DM}(-) \mathrm{n}=60$ & $87.3 \pm 9.6$
\end{tabular}$\quad \mathrm{p}<0.005$

$\mathrm{N}$ 型 5 名 (8.3\%)，P型 7 名（11.7\%）であった。いず れの型でも両者間に出現頻度の有意差は認めなかった。 さらに DM 群にわがままといわれる H型が, 他の型に比 べ多く出現しているということはなかった（表 3 ）.

6 . 食事療法の遵守と性格

食事療法良好群（指示エネルギー量に対し摄取エネル ギー量が士100 kcal 以内）では，S 型性格者の出現頻度 
表 3 性格類型-DM 群 と非 DM 群の比較一

\begin{tabular}{|c|c|c|c|}
\hline & $\mathrm{DM}(+) \mathrm{n}=74$ & $\mathrm{DM}(-) \mathrm{n}=60$ & 有意差 \\
\hline $\begin{array}{l}\text { Z型（zyklothym） } \\
\text { 躁うつ質 }\end{array}$ & $16(21.6 \%)$ & $18(30.0 \%)$ & NS \\
\hline $\begin{array}{l}\text { S 型（schizothym） } \\
\text { 分裂質 }\end{array}$ & $17(23.0 \%)$ & $13(21.6 \%)$ & NS \\
\hline $\begin{array}{l}\text { E型 (epileptisch) } \\
\text { 粘着質 }\end{array}$ & $11(14.9 \%)$ & $10(16.7 \%)$ & NS \\
\hline $\begin{array}{c}\text { H型 (hysterisch) } \\
\text { 顕示性性格 }\end{array}$ & $12(16.2 \%)$ & $7(11.7 \%)$ & NS \\
\hline $\begin{array}{c}\text { N型 (nervös) } \\
\text { 神経質 } \\
\end{array}$ & $6(8.1 \%)$ & $5(8.3 \%)$ & NS \\
\hline $\begin{array}{l}\mathrm{P} \text { 型 (paranoisch) } \\
\text { 偏執病質 }\end{array}$ & $12(16.2 \%)$ & $7(11.7 \%)$ & NS \\
\hline
\end{tabular}

(Kretschmer の類型論を詫摩が改変した分類)

が DM 群 4 名 (11.4\%)，非 DM 群 2 名 (8.3\%) であ るのに対し, 食事療法不良群では同出現頻度が DM 群 13 名 (33.3\%), 非 DM 群 11 名 (30.6\%) であり, DM 群, 非 DM 群とも食事療法不良群には S 型性格者の出現頻 度が有意 $(\mathrm{p}<0.05)$ に高かった。また，他の性格類型に は食事療法良好群，不良群で差は認められなかった（図 。 $4)$.

\section{考案}

DM 透析患者の食事療法遵守率は, 非 DM 透析患者 と比較し，HD ではエネルギー，タンパク質壘とも同等 に遵守されていた．またCAPDでは，エネルギー遵守は DM 透析患者の方がむしろ非 DM 透析患者に比べ有意 に良好であった。食事療法に対する態度は，DM 透析患 者では家族に食事療法をまかせている者が, 非 DM 透析 患者に比へ有意に多かったが，実際に食事を作る調理者 については,「いつも指示量を守っている」,「指示量の 7 割程度は守っている」とした者が, DM 透析患者 $71.6 \%$, 非 DM 透析患者 76.7\%で有意差を認めなかった。また， 1 日当りの体重增加量も両者間に有意差を認めず, 塩分, 水分管理も同等に行われていた。

これらのことより，DM 透析患者が非 DM 透析患者 に比較し, 特に食事療法の管理が悪いとは考え難いと思 われた。しかし，DM 透析患者は神経障害，血管障害な どの合併症の程度により, 社会復帰状況もさまざま ${ }^{8)}$ 食事療法を含めた日常生活の家族への依存度が大きくな る場合がある.今回検討した Karnofsky scale も, 非 DM 透析患者と比較すると有意に低值であった。したがって， DM 透析患者は自立度が悪く他人への依頼心が強い, 自 己中心的，情緒不安定，わがままの印象をもたれる場合 が多いのではないかと考えられた。

DM 透析患者で食事療法良好群の Karnofsky scale

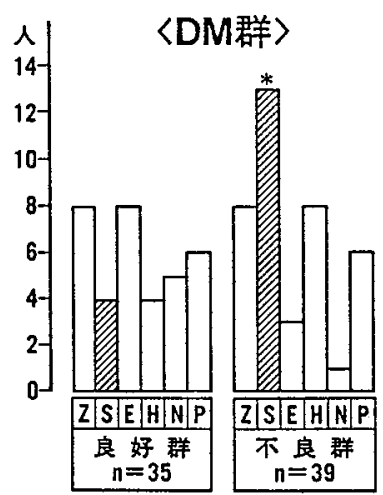

〈非DM群〉

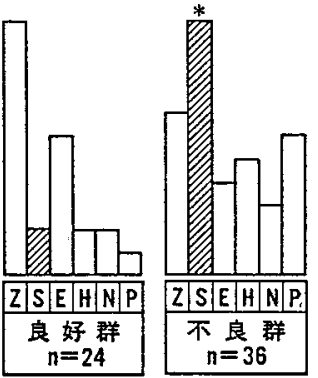

*良好群との有意差 $p<0.05$

図 4 食事療法の遵守の性格類型一DM 群と非 DM 群の比較一

は, $75.4 \pm 13.9$, 不良群は $77.9 \pm 10.4$ で有意差は認めな かった。つまり食事療法は身体活動性の良否とは無関係 に, 患者本人の $\mathrm{DM}$ への理解, $\mathrm{DM}$ 教育の程度, 家族 教育の程度, 家族の協力度等により良否が左右されるも のと思われた。

今回, 糖尿病の透析患者の性格を検討するにあたって, Kretschmer の性格類型論を用いた。一般に性格研究に は，総合的で質的に把握しようとする類型論的研究方法 と, 分析的で量的把握を指向する特性論的研究方法があ る. 類型論は人を本質的なものによって理解しようとす るもので，個人の全体像を容易に把握でき多様な性格の 理解に便利である.しかしその一方，同じ類型の人を画 一化する危険や，質的把握であるので人々の間の程度の 差異を示すものと誤解されやすいなどの欠点もある。ま た，特性論は因子分析（性格検査）によって諸特性の客 観的測定を行うものである．量的測定であるので各人の 程度の比較もできるし，単純化や画一化の危険もないと いう利点がある。しかし個人のもつ全体像を明らかにし ない，その人だけしかもた奴ユニークな特性は無視され るなどの欠点がある ${ }^{6,9,10)}$. 今回，我々の用いた Kretsh. mer (詫摩改変)による方法は前述の類型論的研究方法に 属するものである。

その結果 DM 透析患者, 非 DM 透析患者に, $Z, S, E$, $\mathrm{H}, \mathrm{N}, \mathrm{P}$ 型の各型に出現率の有意差は認めず，DM 透析 患者に特有の性格類型というものは，今回の検討では存 在し得なかった. YG 性格検查で DM 腎症群と非 DM 腎症群の性格プロフィール別頻度を比較した向野らの報 告 ${ }^{11)}$ でも, 両者間に有意差は認められていない.食事療法 の遵守と性格との関係では DM 透析患者, 非 DM 透析 患者ともに食事療法不良群には，S型性格者の出現頻度 が高かった。このS 型性格には，他人と話すより一人で 
いる方が楽，恵気はないのについ冷たい皮肉を言ってし まう，親しみにくい人だという印象を与える，融通がき かない, 自分の私生活を他人に見られることを嫌う，何 か始める前にためらうことが多い，などというような特 徵がある7゙とされている。このような性格的特徵を食事 療法の遵守率が悪いことと直結させるのは危険があると 思われるが，S 型性格傾向が日常の食事管理に関して何 らかの影響があるものと思われた，今回の検討では，透 析患者に抢ける $\mathrm{S}$ 型性格の出現頻度は, DM 群でも非 $\mathrm{DM}$ 群でも同様であり, 特に DM 透析患者で $\mathrm{S}$ 型性格 が多いということはなかった。このことより，DM 透析 患者に性格の偏向が強いとは考兄られなかった。

\section{結論}

1. 食事療法を通して観察した DM 透析患者の性格類 型分布は, 非 DM 透析患者と差を認めず. DM 透析患 者に特にわがままが多いなどの性格の偏向は認めなかっ た.

2. DM透析患者の食事療法の遵守は, 非 DM 透析患 者と同等に行われていた。

3. DM 透析患者, 非 DM 透析患者とも, 食事療法 不良群には $\mathrm{S}$ 型性格者が多かった。

4. DM 透析患者では, 身体活動度が非 DM 透析患 者に比較し有意に低いため，食事管理を家族に依存する ものが多かった。

以上より, 食事療法の面からみた DM 透析患者の身体 的精神的特質は, 身体活動度は低いものの, 性格的には 特に非 DM 透析患者と違いは認められなかった。
文献

1) Krolewski AJ, Warram JH, Christlieb AR : Onset, course, complication and prognosis of diabetes mellitus. In "Joslin's Diabetes mellitus 12 th Ed" ed Marble A, p251-277, Lea, Febiger, Philadelphia, 1985

2) Barbosa J : Diabetes; The science and the art. Arch Intern Med $143:$ 1118-1119, 1983

3）北村信一, 田中剛二：糖尿病食事療法の意義。糖尿 病 $18: 671-675,1975$

4）松岡健平：糖尿病の合併症. 内科 $58: 635-641,1986$

5) Grieco A, Long CJ : Investigation of the karnofsky performance as a measure of the quality of life. Health Psychology 3 : 129-142, 1984

6) 詫摩武俊：心理学. p 102-115, 新曜社, 東京, 1981

7) 詫摩武俊: 性格. p 34-87, 講談社現代新書, 東京, 1971

8）中尾俊之：糖尿病性腎不全による慢性透析患者の病 像. 透析会誌 $19 ： 1061-1068 ， 1986$

9）戸苅正人：類型論と特性論，心理学の基礎知識（東 洋, 大山 正, 詫摩武俊, 藤永 保 編) p 168-169, 有斐閣, 東京, 1983

.10）永井 徹, 詫摩武俊：性格(人格テスト)。臨床透析 $5: 579-583,1989$

11）向野義人, 内藤説也, 村田敏晃, 荒川規矩男: 糖尿 病性腎症による血液透析患者の性格傾向と自己管理 の関係。腎と透析 $21: 897-901,1986$ 